\title{
The upside of trade in health services
}

\author{
(c) $(\mathbb{\theta} \Theta$ OPEN ACCESS \\ Cross border movement of patients and health workers is often portrayed negatively but Johanna \\ Hanefeld and Richard Smith discuss how it can benefit both source and recipient countries as \\ long as the risks are properly managed
}

\section{Johanna Hanefeld associate professor of health policy and systems ${ }^{1}$, Richard Smith professor of health economics ${ }^{2}$}

${ }^{1}$ Faculty of Public Health and Policy, London School of Hygiene and Tropical Medicine, London, UK; ${ }^{2}$ College of Medicine and Health, University of Exeter, Exeter, UK

Trade in health services is the least researched aspect of trade and health. ${ }^{1}$ This is despite the fact that it includes the contentious issues of medical tourism and movement of health workers-both important concerns for health systems, especially in low and middle income countries. Estimates of the global value of medical tourism range from $\$ 60 \mathrm{bn}$ to $\$ 100 \mathrm{bn}$ annually, ${ }^{2}$ which is more than double the estimated $\$ 37 \mathrm{bn}$ available for health development assistance. ${ }^{3}$

Trade in health services, like all trade in services, is regulated by the World Trade Organization as part of the General Agreement on Trade in Services (GATS) (box 1). ${ }^{5}$ But data are extremely limited. Most of the trade in health services occurs within the private sector, and much of it is unregulated and subject to confidentiality and commercial sensitivity restrictions. Nonetheless, available data-for example, on the movement of patients $^{26}$ or health workers ${ }^{7}$ - suggest that trade in health services is growing. In addition, a small but growing number of countries import services to deal with capacity shortfalls in their health systems. These countries are tackling shortages of health workers and access to specialist services through schemes that facilitate medical travel. ${ }^{8}$

\section{Box 1: Rules of trade in health services ${ }^{4}$}

The World Trade Organization (WTO) is a global international organisation dealing with the rules of trade between nations. At its heart are the WTO agreements, negotiated and signed by the bulk of the world's trading nations and ratified in their parliaments.

One of these agreements is the General Agreement on Trade in Services (GATS), which regulates all trade in services, including health services. The GATS agreement covers four modes of trade in health services:

Mode 1: Cross-border delivery of health services (this refers mainly to telemedicine where the service is provided across a border-for example a specialist consultation by email)

Mode 2: Consumption of health services abroad (when the patient travels to access treatment abroad)

Mode 3: Foreign direct investment into the health system of a country (eg, establishment of hospitals)

Mode 4: Temporary movement of health workers

Trade in health services is already affecting health systems in high, middle, and low income countries. Yet it has been given limited considerations in policy debates, including, for example, in the implementation of the sustainable development goals. Despite the limited data on the effect of trade, there has been much comment on the negative effects such trade will have, especially on low and middle income countries. ${ }^{9}$ Here, we examine the evidence that trade in health services can have positive effects on health systems, focusing especially on movement of patients and health workers.

\section{Patients travelling abroad}

Medical tourism has received much attention from politicians and the media. Medical tourism falls under mode 2 of GATS: "consumption of services abroad" (box 1). Popular perceptions here are around wealthy private patients from high income countries such as the US travelling to middle income countries 
where healthcare is cheaper, often combining it with a holiday for recuperation. ${ }^{10}$ Another stereotype is of people from low income countries seeking to access health services

illegitimately - "scrounging"—in high income countries. For example, the UK secretary of state for health singled out the illegitimate use of health services by foreign nationals as a problem for the NHS. ${ }^{112}$ Yet evidence shows that more UK citizens travel abroad for treatment than visit the UK, and that private patients offer a lucrative source of income for the NHS. ${ }^{2}$ Our research indicated that foreign patients accounted for $7 \%$ of private patients in NHS hospitals but provided close to $25 \%$ of all private patient income. In other countries, including South Africa, foreign nationals' use of public health services has similarly been contentious; media reports and political rhetoric focus on poor citizens of neighbouring countries travelling to South Africa to illegitimately access free healthcare. ${ }^{13}$

Although movement of patients is facilitated in various ways, especially in the private sector, there are three main motivations, each with differing effects on health systems. The Maldives provides an example of a government paying for, and sending, patients to receive services abroad. As part of its universal health coverage policy, the government pays for patients to travel to approved providers in India and Sri Lanka ${ }^{14}$ to tackle shortages in specialist care. It is one of a range of government schemes used by small island developing states to address their health system constraints. ${ }^{8}$

Some countries, especially those in South East Asia, have pursued medical tourism as a source of income. ${ }^{15-17}$ Thailand has been most active in this area, and evidence of its effect has been mixed. Although Thailand initially hailed this as a great contribution to its economy, generating $0.4 \%$ of the country's gross domestic product, ${ }^{15}$ a more recent study showed that the economic benefit was more modest. ${ }^{18}$ It also identified that cost of care in the private sector has risen as a result of foreign patients, and that clinicians seem more likely to specialise in medical fields targeting foreign patients. ${ }^{18}$ Not all countries pursue foreign patients as a source of revenue. South Africa provides an interesting example, having signed bilateral agreements with 11 countries in the region that in some cases explicitly cover the travel of patients to South Africa to receive tertiary care in the public sector. Under these agreements South African hospitals act as referral centres for neighbouring countries with weaker health systems. ${ }^{19}$ Although there are financing arrangements between governments to cover these schemes, the language of these agreements is one of solidarity and assistance by the South African government to its neighbours.

Finally, most patients travel for treatment without encouragement or government schemes. Much attention is given to high end medical tourism, which in many instances has been described as a potentially great business opportunity and a good deal for patients in stretched high income country health systems. However, evidence suggests that the majority of such travel is between low and middle income countries, ${ }^{6021}$ where patients may seek access to care not available in their home country. Although this does include people on the highest incomes in low income countries who may travel to middle and high income countries to access high end medical treatment-for example, wealthy Nigerians or high income patients from eastern Africa or the Middle East travelling to India and Thailand ${ }^{218}$ - studies suggest that the majority of patients travelling abroad to receive care are far from the image of the empowered consumer accessing the best service at the best price. Nor are they simply travelling to access treatment covertly in the public health system of another country. Foreign patients accessing care may, of course, also be simply an effect of the general increases in population movement rather than being the main motivation for travel. ${ }^{22}$

Continuity of care and consistency of patient records remain concerns for all patients who travel and are currently not regulated through an international mechanism or treaty. Although the health security risk of a patient spreading an infectious disease is often cited as a concern, ${ }^{23}$ such cases have remained rare. It is far more common for travelling patients to experience adverse outcomes such as treatment failure or side effects once they have returned home. ${ }^{2425}$

\section{Health workers travelling abroad}

There is a long tradition of health workers moving across national borders. It is often difficult to distinguish between those moving permanently in pursuit of better employment opportunities (which is not included as a trade in services under GATS) and those moving temporarily to provide a service in another country. Managed mobility occurs through bilateral and regional trade and economic cooperation arrangements, where governments agree the exchange of health workers-often to fill staff shortages or demographic challenges such as an ageing population-while generating employment and economic opportunities for health workers from another. This type of trade has also been shown to contribute to economic development informally through the remittances that health workers send to their family at home. ${ }^{26}$ Examples of this type of scheme include export of nurses by the Philippines' government, ${ }^{27}$ and training and exchange schemes in the Caribbean to tackle regional migration and health worker shortages. ${ }^{28}$

Little is known, however, about movement of health workers outside the public sector or where health workers may be explicitly recruited across borders. This includes the extent to which such schemes contribute to a "brain drain" from source countries where health workers are scarce to destination countries that are already better supplied. ${ }^{2930}$ The effect of health worker emigration overall is complex, but the evidence suggests that, much like patient mobility, with the right type of regulation and management, movement of health workers as a trade in services can have positive effects for both source and destination countries.

\section{Effect on health systems}

The effect on health systems of patient and health worker movement differs depending on the type of movement. With patients, government schemes, such as in the Maldives, seem to provide a possible avenue through which some low income countries can achieve universal health coverage. At the same time the evidence emphasises the importance of monitoring cost and equity concerns.

Where countries are attracting foreign patients concerns of a two tier health system have been raised. Research from Thailand and other countries, ${ }^{217} 18$ shows, for example, that higher incomes offered by foreign patients may lead to doctors focusing on specialties that service foreign patients rather than those needed by the countries' population. It is therefore important to regulate against potentially negative effects on equity, including increased cost of services for domestic patients and movement of health workers into the private sector. However, research shows that foreign patients provide a potentially lucrative source of income for health systems. This is particularly important for middle income countries seeking to expand coverage and quality of health services for their domestic population. 
Patients travelling for treatment across borders can also allow for more efficient use of resources if countries have spare capacity and access to specialist treatment can be increased. More importantly, foreign patients are often considered simply as a cost, rather than as one aspect of trade in services. For example, the UK media have given much attention to the perceived negative effects of medical tourism on the NHS without any discussion or mention of the many non-UK nationals working within the system and the benefits arising from this. Rather than viewing these trends separately, we should recognise them as part of the same trade, which in turn reflects a more interconnected world where mobility is the new norm. Any balanced debate on costs arising to destination countries (of patients) ought to include discussion of the numbers of foreign health workers recruited and under which conditions, as well as the possibility of a rebate to their home countries.

\section{Adequate protection}

What is common across the different types of patient and health worker mobility is that they all provide potential opportunities to health systems, while the challenges or potential risks could be managed through explicit governance measures between countries-for example, covering equity concerns around health worker movement, while further guaranteeing patient safety and continuity of care. Better regulation is also likely to improve the efficiency of trade in services, again strengthening its potential as a route to increase coverage and services. Health governance mechanisms such as international regulations or World Health Organization resolutions are an obvious way to achieve this.

\section{Key messages}

Trade in health services can solve health worker shortages, raise revenues, and increase systems efficiency

The substantial trade in health services occurs mainly in the private sector, limiting the data

Movement of patient and health workers has been largely ignored in global health debates

To maximise the potential benefits, global governance mechanisms and national regulatory approaches are needed to guard against equity problems

More research is urgently required to inform this global governance

Contributors and sources: $\mathrm{JH}$ has researched trade in health services for the past decade. She is currently researching the effects of patient and health worker mobility and migration on health systems in southern Africa. RS has researched and written on trade and health for 20 years and has worked as an adviser to international agencies and national governments on numerous occasions. This article arose from discussions on how best to adapt health systems to mobility and migration in the $21 \mathrm{st}$ century. Both authors contributed to drafting the manuscript and have read and agreed with the final version of the paper.

Competing interests: We have read and understood BMJ policy on declaration of interests and have no relevant interests to declare.

Provenance and peer review: Not commissioned; externally peer reviewed.

1 Smith R, Blouin C, Drager N, Fidler D. Trade in health services and the GATS. In: Mattoo A, Stern R, Zanini G, eds. A handbook of international trade in services. Oxford University Press, 2007:437-5810.1093/acprof:oso/9780199235216.003.0011.
2 Hanefeld J, Horsfall D, Lunt N, Smith R. Medical tourism: a cost or benefit to the NHS?PLoS One 2013:8:e70406. 10.1371/journal.pone.0070406 24204556

3 Dieleman JL, Schneider MT, Haakenstad A, etal . Development assistance for health: past trends, associations, and the future of international financial flows for health. Lancet 2016;387:2536-44. 10.1016/S0140-6736(16)30168-4 27086170

4 Smith RD, Chanda R, Tangcharoensathien V. Trade in health-related services. Lancet 2009;373:593-601. 10.1016/S0140-6736(08)61778-X 19167053

5 Blouin C, Drager N, Smith R, eds. International trade in health services and the GATS current issues and debates. World Bank, 2006.

6 Crush J, Chikanda A. South-South medical tourism and the quest for health in Southern Africa. Soc Sci Med 2015;124:313-20. 10.1016/j.socscimed.2014.06.025 24973022

7 Buchan J. Migration of health workers in Europe: policy problem or policy solution. In: Human resources for health in Europe. European Observatory on Health Systems and Policies, 2006: 41-62.

8 Suzana M, Walls $\mathrm{H}, \mathrm{Smith} \mathrm{R}$, Hanefeld J. Achieving universal health coverage in small island states: could importing health services provide a solution? BMJ Global Health, 2018

9 Hopkins L, Labonté R, Runnels V, Packer C. Medical tourism today: what is the state of existing knowledge?J Public Health Policy 2010;31:185-98. 10.1057/jphp.2010.10 20535101

10 Connell J. Medical tourism: Sea, sun, sand and ... surgery. Tour Manage 2006;27:1093-10010.1016/j.tourman.2005.11.005.

11 Hanefeld J, Lunt N, Smith R. Paying for migrant healthcare. BMJ 2013;347:66514. 10.1136/bmj.f6514 24174641

12 Hanefeld J, Mandeville K, Smith R. Making "health tourists" pay for care. BMJ 2017;356:j771. 10.1136/bmj.j771 28202447

13 Walls HL, Vearey J, Modisenyane M, etal . Understanding healthcare and population mobility in southern Africa: the case of South Africa. S Afr Med J 2015;106:14-5. 10.7196/SAMJ.2016.v106i1.10210 26792300

14 Suzana M, Chongsuvivatwong V. Changes in access to and costs of overseas treatment after the introduction of universal health coverage in the Maldives: Findings from surveys and the analysis of claims data. Health Serv Manage Res 2015:28:47-5710.1177/0951484815611147.

15 NaRanong A, NaRanong V. The effects of medical tourism: Thailand's experience. Bull World Health Organ 2011;89:336-44. 10.2471/BLT.09.072249 21556301

16 Pachanee CA, Wibulpolprasert S. Incoherent policies on universal coverage of health insurance and promotion of international trade in health services in Thailand. Health Policy Plan 2006;21:310-8. 10.1093/heapol/czl017 16728511

17 Pocock NS, Phua KH. Medical tourism and policy implications for health systems: a conceptual framework from a comparative study of Thailand, Singapore and Malaysia. Global Health 2011;7:12. 10.1186/1744-8603-7-12 21539751

18 Noree T, Hanefeld J, Smith R. Medical tourism in Thailand: a cross-sectional study. Bull World Health Organ 2016;94:30-6. 10.2471/BLT.14.152165 26769994

19 Crush J. Patients without borders: medical tourism and medical migration in Southern Africa. 2012. https://www.africaportal.org/publications/patients-without-borders-medicaltourism-and-medical-migration-in-southern-africa/

20 Lunt N, Horsfall D, Hanefeld J. Handbook on medical tourism and patient mobility. Edward Elgar Publishing, 2015. 10.4337/9781783471195

21 Ormond M. Neoliberal governance and international medical travel in Malaysia. Routledge, 2013.10.4324/9780203077566

22 Vearey J, de Gruchy T, Kamndaya M, Walls HL, Chetty-Makkan CM, Hanefeld J. Exploring the migration profiles of primary healthcare users in South Africa. $J$ Immigr Minor Health 2018;20:91-100. 10.1007/s10903-016-0535-7 27909937

23 Rogers BA, Aminzadeh Z, Hayashi Y, Paterson DL. Country-to-country transfer of patients and the risk of multi-resistant bacterial infection. Clin Infect Dis 2011;53:49-56. $10.1093 / \mathrm{cid} / \mathrm{cir} 27321653302$

24 Smith R, Lunt N, Hanefeld J. The implications of PIP are more than just cosmetic. Lancet 2012;379:1180-1. 10.1016/S0140-6736(12)60166-4 22305764

25 Lunt N, Smith RD, Mannion R, etal . Implications for the NHS of inward and outward medical tourism: a policy and economic analysis using literature review and mixed-methods approaches. NIHR, 2014.

26 Plotnikova $\mathrm{E}$. The role of bilateral agreements in the regulation of health worker migration In: Health professional mobility in a changing Europe. WHO, 2014: 325.

27 Yeates N. Globalizing care economies and migrant workers: Explorations in global care chains. Palgrave Macmillan, 2009.

28 Salmon ME, Yan J, Hewitt $\mathrm{H}$, Guisinger V. Managed migration: the Caribbean approach to addressing nursing services capacity. Health Serv Res 2007;42:1354-72. 10.1111/j.1475-6773.2007.00708.x 17489919

29 Oladeji BD, Gureje O. Brain drain: a challenge to global mental health. BJPsych Int 2016;13:61-3. 10.1192/S2056474000001240 29093905

30 Labonté R, Sanders D, Mathole T, etal . Health worker migration from South Africa: causes, consequences and policy responses. Hum Resour Health 2015;13:92. 10.1186/s12960-015-0093-4 26635007

31 Lunt N, Horsfall D, Smith R, Exworthy M, Hanefeld J, Mannion R. Market size, market share and market strategy: three myths of medical tourism. Policy Polit 2014;42:597-61410.1332/030557312X655918.

Published by the BMJ Publishing Group Limited. For permission to use (where not already granted under a licence) please go to http://group.bmj.com/group/rights-licensing/ permissions This is an Open Access article distributed in accordance with the Creative Commons Attribution Non Commercial (CC BY-NC 4.0) license, which permits others to distribute, remix, adapt, build upon this work non-commercially, and license their derivative works on different terms, provided the original work is properly cited and the use is non-commercial. See: http://creativecommons.org/licenses/by-nc/4.0/. 